\title{
THE STUDENTS' DEMAND FULFILLMENT AND PERSONALITY IN USING BLACKBERRY
}

\author{
Dr. Chairiawaty.,MSi ${ }^{1}$, Dr. Yenni Yuniaty.,MSi ${ }^{2}$, Anne Maryani.MSi ${ }^{3}$ and \\ Nurahmawaty.MSi ${ }^{2}$ \\ ${ }^{1}$ Faculty of Engineering, UNISBA, ${ }^{2}$ Faculty of Communication Science, UNISBA and \\ ${ }^{3}$ Faculty of Communication Science, UNISBA
}

\begin{abstract}
There's a wide range of facilities for all. The spread of Cellular phone equipped with internet connection features of subscriptions, such as Blackberry, allowing children especially teens to be able to search for information relating to anything that can satisfy their curiosity very quickly. Blackberry with full facilities into a choice used by many, especially facilities free message through BBM (Blackberry Messenger). Almost all children and adolescents into the BB users. Behaviors that can be seen on the face of the children and young people is that they become very dependent on public Blackberry, hardly a time that does not use Blackberry, so when they do not learn to concentrate, they are absorbed in their own world, in other words no longer matter in socialite them, they have their own world. In addition, teens who do not have a BB as hard as possible will strive to have it in order to be aligned with other friends and can also use the facility.
\end{abstract}

Based on the background and phenomenon mentioned, this research studied about "The The Student's Demand Fulfillment and Personality in Using Blackberry." The research was aimed at finding out: (1) the intensity of blackberry use with the cognitive and affective fulfillment of The Junior High School Students, (2) the intensity of blackberry use with the students' Tense Release, (3) the intensity of blackberry use with the students' Personal Integrative; (4) the intensity of blackberry use with the students' Socially Integrative; (5) the intensity of blackberry use with the students' Confidence ; (6) the intensity of blackberry use with the students' Tolerance; (7) the intensity of blackberry use with the Whole students' Fulfillment; (8) the intensity of blackberry use with the students' Personality as a whole.

The research used a quantitative approach with the explanatory survey method. The Theories used were: Cognitive Psychology, Technology Determinism, and Uses and Gratification. The population of the research was The Junior High School students. By using random sampling technique, it was taken 5 schools and 200 students as the sample. The data were taken through questionnaires. The data obtained were analyzes by using the statistical test of correlation. The results of the research show that almost in every aspect of the intensity use of Blackberry with the students' demand fulfillment (tense release, personal integrative and social integrative) as well as with their personality had no significant correlation or if there were, the correlation was very low. This means that the use of blackberry did not give any impact to the personality (cognitive, affective or tolerance) of the students, or in other words it could be said that the development of communication technology gave very little impact on the students' personality and demand fulfillment. Yet, since the research also found out that most of female students used Blackberry for one hour without stopping, the researcher then gave The Guidance book to the Junior High School students about "Smart and Wise in Using Blackberry".

\section{KEY WORDS}

Iintensity of Blackberry use, demand fulfillment, personality

DOI : 10.5121/acij.2013.4603 


\section{Background}

The rapid development of information technology and telecommunication has shifted the people's way of life including the teenagers. It allows the implementation of new ways for more efficient production, distribution and consumption of goods and services on one hand, yet on the other hand it will also bring negative effects.

New communication technology such as Blackberry allows a convergent medium to facilitate mediated interpersonal communication. Convergence has changed the relationship between technology, industry, market, lifestyle and audiences. In short, convergence changes relationship patterns of production and consumption, which will give impacts on various fields such as economics, politics, education, and culture. Changes affect social relations in the family as micro and macro communities. These changes are characterized by an increased use of incredibly convergent media.

The development of the digital information and cyberspace today has changed the city family portrait. Family harmony, as a source of information and early socialization has been shifted into the digital family, the children become digital native and a digital immigrant adults. They have a dedicated space to continue to connect with the digital information that takes the time to meet and communicate among family members directly. Places and spaces where families gather are now being replaced by electronic or virtual space. Space close to being socially distant, distant space while being close to the social, as driven to form virtual: spatially distant, but close virtually. The increasing number of sites such as face book, twitter, and my space made communication and exchange information more easily as well as a place to make a free blog on the internet like word press, blog spot and so forth. Technology was speeding so fast, that deliver public in a process of social change penetrating into the smallest unit of society is the family.

Changes in the information technology have created a solitary man. Model of life based on the principles of individualism and economic has created a model of a lonely life in a crowd. The development of information technology and global telecommunications today have swallowed various dimensions of family harmony. According to Yasraf (2004:476) through the development of various forms of information and communication technology that is instantaneous, fast, and virtual, then the interaction (face to face) is now taken over by interactive relationships mediated by social media. Any recollection or memory of a place, and time with family is now taken over by the memory of a computer, phone, i- Pad and others. that can store, recall, and display back everything. Memory inherent nature of mind in which the so-called sense and feeling, and other natural properties, now has been taken over by the computer artificial memory, reminder machines, electronic records, or digital agenda. Blackberry as a result of the development of cutting-edge technology has also grown very rapidly in this life.

\section{Research Statement}

Based on the background and a phenomenon that has been described, the formulation of the problem is as follows: "How is the student's demand fulfillment and personality in using ?".

\section{Identification of Problems}

1. How is student's cognitive fulfillment through the intensity use of Blackberry?

2. How is student's affective fulfillment through the intensity use of Blackberry?

3. How is the students' tension release through the intensity of Blackberry? 
4. How is the students' integrative personal through the intensity use of Blackberry?

5. How is the students' integrative social through the intensity use of Blackberry?

6. How is the students' confidence through the intensity use of Blackberry?

7. How is the students' tolerance through the intensity use of Blackberry?

8. How is the student's overall demand fulfillment in using Blackberry?

9. How is the student's overall personality in using Blackberry?

\section{Urgency of The Research}

Humans will find information in many different ways they like. Curiosity arose because he wanted someone who always tries to increase their knowledge, thus unwittingly someone needs information to satisfy the curiosity. If the curiosity is something very urgent, it is something that will continue to be sought until he found the information that really suits his desires and needs. The urgency of this study is to examine the needs of junior high school students and their personality in using blackberry . So that the implications can be anticipated among junior high school students.

\section{Framework}

The Grand Theory used was the theory of Cognitive Psychology which is the study of mental processes or thoughts and how the information is obtained, presented and transformed as knowledge. Cognitive psychology is also called information processing psychology. Basic principles of cognitive psychology focuses on: (1) active learning, (2) learning through social interaction, and (3) Learning through experience alone

Cognitive psychology theory developed Gestalt theory (Mex Weitheimer) which stated that experience was structured in the form of a whole. There are two mandatory laws in Gestalt theory, namely: (a) clarity, and (b) closure (totality). Important concept in the theory of INSIGHT, namely: observation or sudden understanding of the relationship between the parts in a problem situation.

\section{A. Learning Cognitive-Field Theory of Lewin}

Departing on Gestalt theory, Lewin developed a theory of learning based on Life Space (psychological world of the individual's life). Each individual is in the field of psychological strength, it's called Life Space consisting of two elements i.e the personality and social psychology. Lewin stated that the learned behavior is an attempt to hold a reorganization / restructuring (of the contents of the soul). Behavior is the result of the interaction between the forces of good from the inside (goals, needs, inner pressure, etc.) and external (challenges, problems).

\section{B. Cognitive Development (Jean Piaget)}

In his theory, Piaget's viewed that the gradual process of thinking as the activity of the intellectual function of the concrete to the abstract. He used the term scheme: the pattern of behavior that can be repeated associated with:

* Reflex traits (breathing, eating, drinking)

* Scheme mental (behavioral patterns are difficult to be observed, and which can be observed) 
According to Piaget individual cognitive development includes four levels, namely:

(1) sensory motors;

(2) pre-operational;

(3) concrete operational and

(4) formal operational

Besides, individual cognitive development includes four stages, namely:
a. Maturity
b. Experience physical / environmental
c. Social transmission
d. Equilibrium / self regulation

Piaget also saw intelligence from three aspects, namely:

- Structure (scheme): patterns of behavior that can be repeated

- Content (content): which specific behavior patterns (in the face of problems)

- Function (function): connected one way to achieve intellectual advancement.

\section{Discovery Learning from JA Brunner}

Brunner theory states that children should actively participate in learning in the classroom. The purpose of the Discovery Learning is that student organized method of presenting in a way in which children can learn the material, according to the child's level of ability.

The act of discovery of Burner:

1. The existence of a potential rise in intellectual

2. More intrinsic rewards than extrinsic emphasized

3. Pupils who learn how to find means that the student mastered the method of discovery learning

4. Pupils prefer to recall information

Ausubel also put his idea about cognitive psychology. He revealed expository teaching theory, which can be well organized or presented in order to generate understanding and good reviews to discovery learning.

The cognitive psychology theories as discussed above comprised as the Grand Theory used in this study. Now, we discuss The Middle Range Theory. For the middle range theory, it was used the Technological determinism of Marshall McLuhan.

\section{TECHNOLOGILA DETERMINISM THEORY}

Marshall McLuhan put this theory forward first time in 1962 in his essay The Guttenberg Galaxy: The Making of Typographic Man. The basic idea of this theory is that the changes that occur in a variety of ways to communicate will shape human existence itself anyway. Technology shape how people think and behave in society. And the technology is finally directing people to move from one century to another technology.

McLuhan thinks that our culture is shaped by how we communicate. At the very least, there are several steps that worth listening to. First, the communication technology led to the discovery of cultural change. Second, changes in the types of communication eventually forming 
human life. Third, as McLuhan said that "We are forming equipment to communicate, and eventually the equipment that we use to communicate the eventual shape or influence our own lives".

We learn, feel and think about what we will do as the message which is received through communication technologies providing for it. Providing messaging and communication technologies shape our own behavior. In particular, the convergence of information technology led to the shifting patterns of human behavior at work, learn, manage business institution or company, to run the government, as well as in trade.

In the context of interpersonal relationships, it ensued a dramatic change on the patterns of interpersonal communication and self actualization with the advent of web-blog, Mailing List, virtual communities (groups) like face book, twitter, description, and others. Convergent Media have entered the human feelings and affect our daily lives. Furthermore, we want to use it again and again. Even McLuhan came to the conclusion that the media is the message itself (the medium is the message).

Media is nothing but a tool to reinforce, strengthen and expand the functionality and human feelings. In other words, each new media discoveries extend human abilities and skills. For example, convergent media will broaden horizons, skills and knowledge including our ability. With convergent media, we will be able to "see the world", either personally, groups or socially.

McLuhan is the core of the theory of technological determinism. The point is the discovery or development of communications technologies that change the fact of human culture. If Karl Marx assumed that history is determined by power production, according to McLuhan human existence is determined by changes in the communication model.

If you want to take a look at this time there is no one aspect of human life that is not in contact with what is called convergent media. Starting from the living room, kitchen, school, office, friends, and even religion, are all associated with this medium. Hardly ever we can free ourselves from convergent media in our daily lives.

The presence of the so-called convergent media and social media into a media time suck someone either in the room or in the domestic public. Communication within a family also became involved change with the development of the social media. Before social media was found, at a meeting at dinner or watching television together in the living room became a weekly and even daily routines. Having no social media, these habits began to erode. It was due to become a place of social media in informing, including the activities and position of and the role of a person in a social group.

The development of communication technology now makes it easier for family members, especially children to access anything, anytime. There's a wide range of facilities for all. The spread of Cellular phone equipped with internet connection features of subscriptions, such as Blackberry, allowing children especially teens to be able to search for information relating to anything that can satisfy their curiosity very explosive. Urban children spent more time in the room. Activities they do in the room can vary, but they often make social media as a source for information to help resolve the tasks school / college in addition to hack social relationship with his peer group. The dining room and family room are the common rooms where the whole family gathered. With the variety of rules that restrict the movement of them, then they assume room is the best place to express themselves. 
Blackberry with full facilities into a choice used by many, especially facilities free message through BBM (Blackberry Messenger). Almost all children and adolescents into the BB users. Behaviors that can be seen on the face of the children and young people is that they become very dependent on public $\mathrm{BB}$, hardly a time that does not use $\mathrm{BB}$, so when they do not learn to concentrate, they are absorbed in their own world, in other words no longer matter in the socialization, they have their own world. In addition, teens who do not have a BB as hard as possible will strive to have it in order to be aligned with other friends and can also use the facility. With the new communication technology, world can be in one's hand. Just click your finger, then you can search everything you like in whatever place you are interested.

\section{E. USES and GRATIFICATION THEORY}

One theory that emerged in the study of mass communication is the theory of Uses and Gratification. This theory was used as the Applied Theory for this study. This theory discusses the use of the mass media by the active audience. In other words, the use of media by the audience assumed as a behavior in which the audience actively and consciously choose to consume certain media. McLeod and Backer (in Baran and Davis, 2000) states that a person based on their respective interests will choose which media will be consumed and get a reciprocal fulfillment of the requirements wanted.

There are several assumptions underlying this theory, both proposed by Katz, Gurevitch, and Hass (1974), Dominick (1996) or by McQuail (2005). The basic assumptions are among other things;

1. Audience is a group of active consumers who consciously use the media in connection with the fulfillment of the needs of both personal and social needs are converted into certain motives.

2. Selection of media and its contents is a reasoned action and has a purpose and a certain satisfaction in accordance with public initiatives.

3. All factors that exist in the formation of active audiences like motif, which is expected gratuities and gratuities are accepted in principle be measured because the audience has awareness of self sufficient regarding the use of media, interest and motivation that can be evidence for investigators.

4. Mass media compete with other sources in order to meet the needs of the audience.

According to its founder, Elihu Katz, Jay G. Blumler, and Michael Gurevitch (in Mercy, 2005), uses and gratifications researching the origins of the psychological and social motives, which raises certain expectations from the mass media or other sources, which lead to different patterns of media exposure (or engagement in activities others), and raises the fulfillment motif and other consequences.

The conceptual framework of the study can be described in the following diagram : 


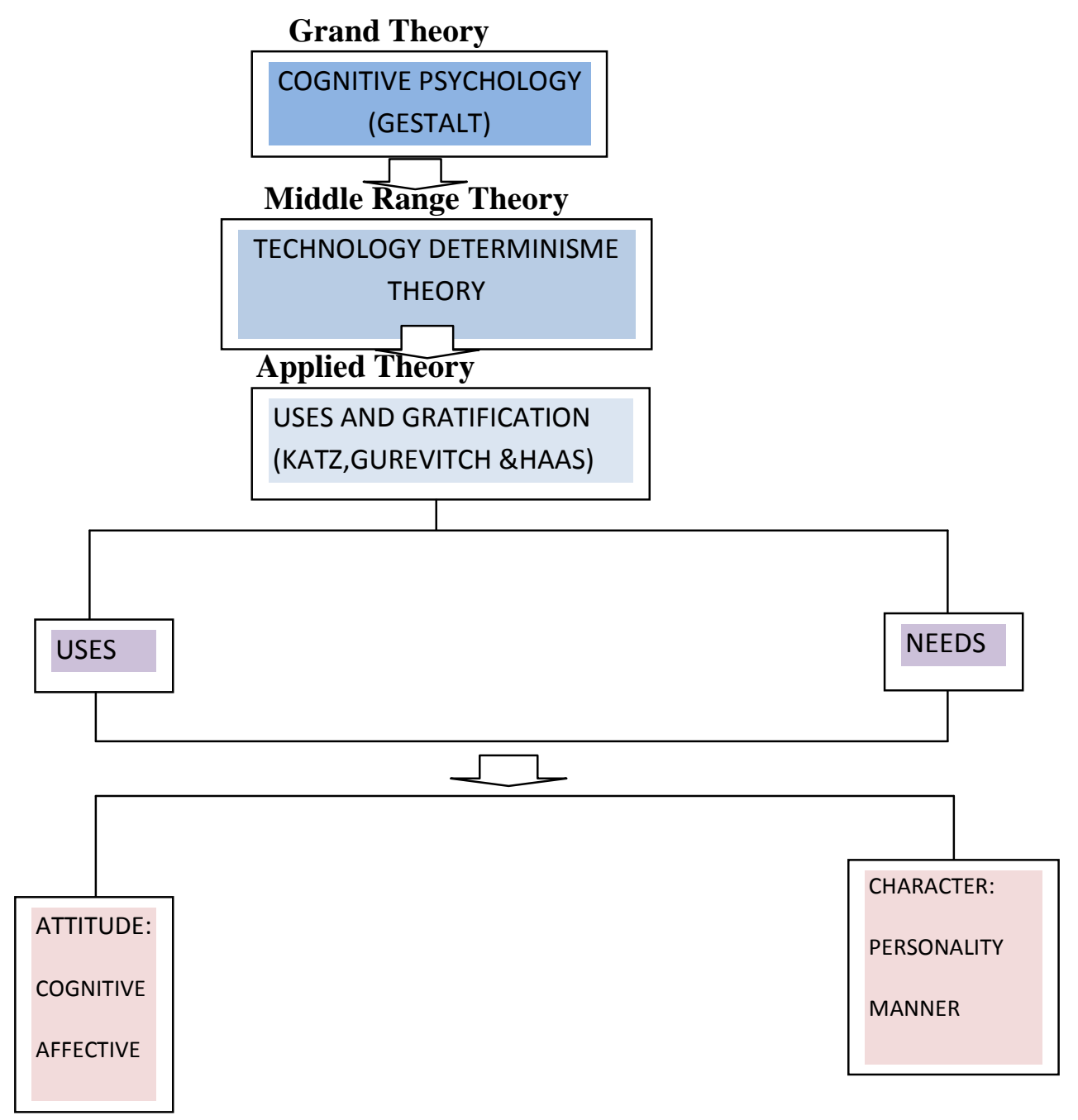

Picture: Framework Research

\section{Research Method}

The study, entitled the student's demand fulfillment and personality in using Blackberry used a quantitative approach, in which the method is often called the traditional method, positivistic, scientific and discovery methods. This method as a scientific method or scientific because has met the scientific principles that are concrete or empirical, objective, measurable, rational, and systematic. Research data are described in the form of figures and statistical analyzes.

This study used two correlated variables. Correlation analysis which "discussed the degree of relationship between variables was known as correlation analysis. Measurement used to determine the degree of relationship, especially for quantitative data, is called correlation coefficient "(Sudjana, 2002:367). This study aims to quantify the relationship between the three variables, namely the use of the Blackberry as the first variable, the second variable needs, and personality as a third variable. 
To predict the dependent variable from knowledge of the independent variables. Act means that as the independent variable $(\mathrm{X})$ is the use of a Blackberry and the dependent variable was the demand fulfillment (Y1) and personality (Y2).

\section{Data Collection Techniques}

The data collection techniques used were as follows:

\section{Questionnaire}

Questionnaire is a set list of questions or statements are arranged systematically, to be filled by the respondents. Questionnaire given to the person concerned and the shape of questionnaire structured or closed, in which respondents live or filler questionnaires provide certain signs. In this case the questionnaire will be distributed to be filled by the students of class II of the Junior High School (SMP) in Bandung, which consists of 5 school, spread in 5 areas in Bandung.List of questions in the questionnaire is based on the operationalization of the variables of the variable use of the Blackberry, the variable needs, and personality variables.

\section{Library studies}

Literature searches conducted through sources have been there in the book which deals with that have been retrieved from the object of research itself. This is done to obtain useful and related information to investigators.

\section{Interview}

Interview is a process to obtain information and research purposes by way of question and answer with face-to-face between the interviewer and respondent or the person being interviewed. Researchers interviewed people who have an involvement in this study, namely the Junior High School students.

\section{Online Data Search}

Collecting data with online data retrieval in question is in order to perform data retrieval via the Internet, especially with regard to the profile of the Blackberry as well as supporting data relating to the use of the Blackberry.

\section{Instrument Validity and Reliability}

\section{1.. Instrument validity}

According Sugiyono (2009: 173) "Valid means that the instrument can be used to measure what should be measured". A study is valid if there are similarities between the data collected by the data actually happened on the object under study. While the validity of the test is the test / examination conducted by the researchers of the data obtained to get the valid data. Validity can be defined as a characteristic of the size associated with the level of measurement of a test tool (questionnaire) to measure correctly what the researcher wants to measure. Testing the validity of a research instrument that has a level ordinal scores, validity coefficient formula used is Spearman Rank, namely: rs = coefficient Validity 


\section{Reliability}

Reliability means steadiness or constancy. It shows a sense of "whether an instrument can measure something consistently measured over time. The key word is consistency, constancy, or do not change "(Nurgiyantoro, 2004:339). Reliability of the instrument in this study is done in a way to test the questionnaire for respondents. A measuring instrument is said to have reliability when used multiple times by the same investigator or researcher who else still gives the same result (Grace, 1996:17).

Reliability is an index that indicates the extent to which a measuring device can be trusted. The goal is to determine the consistency of gauges or instruments used, if the study measured two or more times and the same conclusion, then the measuring device called a reliable (Singarimbun and Effendi, 1986:140).

A set of questions to measure a variable is said to be reliable and succeeded in measuring our variable measuring if the reliability coefficients greater than or equal to 0.700. (Kaplan and Saccuzo, 1993:46). Reliability coefficients of the two parts can be obtained by using the Spearman-Brown formula, namely:

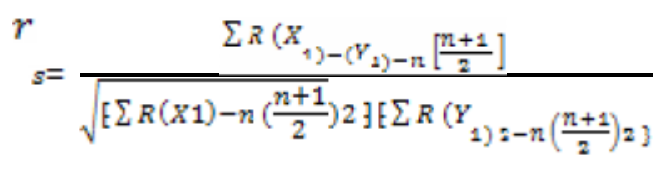

\section{Analysis}

The data that have been obtained will be processed in a simple and presented in tabular form and analyzed qualitatively and quantitatively.

a. Quantitative analysis used the calculation statistics tool based on the identification of the problem

b. Qualitative analysis the analysis used to interpret the test result data link between the use of Blackberry with student needs and personality. In this study the authors used ordinal data to measure the indicators variables, because these data allow researchers to sort respondents on the basis of his opinion on certain objects, from the lowest level to the highest level. Respondents' answers were scored in the form of Likert scale. The weight rating for each question on the questionnaire are as follows:

Strongly Agree (SS): 5

Agree (S): 4

Neutral (N): 3

Disagree (TS): 2

Strongly Disagree (STS): 1, except for the question of personality, the weight of his judgment is reversed.

After the scores obtained, then statistically analyzed by means of:

\section{Correlation analysis}

Correlation analysis used Spearman rank correlation analysis. It is used to determine the degree the use of Blackberry with the dependent variable: the student's demand fulfillment and personality. 
The symbol Spearman rank correlation coefficient formula rs.

When faced shaped item ordinal scale (attitude scale), then

Spearman rank correlation for the value of the i-th item is:

$\boldsymbol{r} S=\frac{\sum x^{2}+\sum y^{2}-d i^{2}}{\sqrt[2]{\sum_{x} 2 \sum_{y}^{2}}}$

where: $\mathrm{R}(\mathrm{X})=$ Ranking value $\mathrm{X}$

$\mathrm{R}(\mathrm{Y})=\mathrm{Y}$ values Ranking

Spearman Rank correlation coefficient formula:

$r s=1-\frac{6 \sum d^{2}}{n\left(n^{2}-1\right)}$

$r s=1-\frac{6 \sum d^{2}}{n\left(n^{2}-1\right)} \ldots \ldots \ldots . .(1)$. If there is no value of $\mathrm{X}$ and $\mathrm{Y}$ are $\mathrm{t}$
Where
$\mathrm{rs}=\frac{\sum x^{2}+\sum y^{2}-d i^{2}}{2 \sqrt{\sum_{x} 2 \Sigma_{y} 2}} \ldots$ (2). If there are the same number in the variable $\mathrm{X}$ or $\mathrm{Y}$.

with :

$\sum_{X} 2=\frac{N^{3}-N}{12}-\sum T_{x}$ dan $\sum T_{x}=\sum \frac{\left.t^{s-t}\right)}{12}$

$\sum_{y} 2=\frac{N^{s}-N}{12}-\sum T_{y}$ dan $\sum T_{y}=\sum \frac{\left.t^{t} t\right)}{12}$

Description:

rs: Spearman Rank correlation coefficient.

n: number of samples.

$\Sigma T$ x: correlation factor $\mathrm{X}$.

$\Sigma T y:$ correlation factor Y.

in: Difference in rank $\mathrm{X}$ and $\mathrm{Y}$.

$\mathrm{t}$ : Number of data which has rank twins.

The magnitude of the correlation coefficient is $-1 \leq \mathrm{r} \leq 1$, which shows:

a. If $r s=1$ or close to 1 , then the relationship between two variables is very strong and has a direct relationship (if the variable $\mathrm{X}$ rises, the variable $\mathrm{Y}$ rises).

b. If $r s=0$ or close to 0 , then the relationship between two variables is very weak or no effect at all.

c. If $\mathrm{rs}=-1$ or close to -1 , then the relationship between the two variable has a very strong and inverse properties (if the variable $\mathrm{X}$ rises, the variable $\mathrm{Y}$ down or vice versa).

d. To find out how much the relationship variables $\mathrm{X}$ and $\mathrm{Y}$, Guilford used criteria (Grace, 2005:29), as follows: 
Advanced Computing: An International Journal (ACIJ), Vol.4, No.6, November 2013

\section{Against Interpretation Guidelines for Giving Correlation Coefficient The value of rs Level Relations}

\begin{tabular}{|c|l|}
\hline Coefficient & \multicolumn{1}{c|}{ The Relationship Level } \\
\hline$<0,20$ & Very low relationship \\
\hline $0,20-0,40$ & Low but definite relationship \\
\hline$>0,40-0,70$ & Significant relationship \\
\hline$>0,70-0,90$ & High relationship, strong \\
\hline$>0,90$ & Relationships are very strong, reliable \\
\hline
\end{tabular}

(Rakhmat, 2007:29)

\section{Analysis Determination Coefficient}

To determine the relationship between the use of Blackberry on the Fulfillment and personality of students

then use the following formula:

$\mathrm{Kd}=\mathrm{rs}^{2} \mathrm{x} 100 \%$

Where: $\mathrm{Kd}=$ coefficient of determination

rs $=$ coefficient of correlation

\section{Hypothesis Testing}

Once the correlation coefficient (rs) is obtained, it can be tested between the use of Blackberry with fulfilling the needs and personality of the students, whether significant or not that was expressed in terms of the formulation of the hypothesis $\mathrm{H} 0$ and $\mathrm{H} 1$ with the following conditions:

H0: $\rho=0$, means that the use of the Blackberry does not correlate with the fulfillment of the needs and personality of students

H1: $\rho \neq 0$, means that the use of the Blackberry correlates with the fulfillment of the needs and personality of students

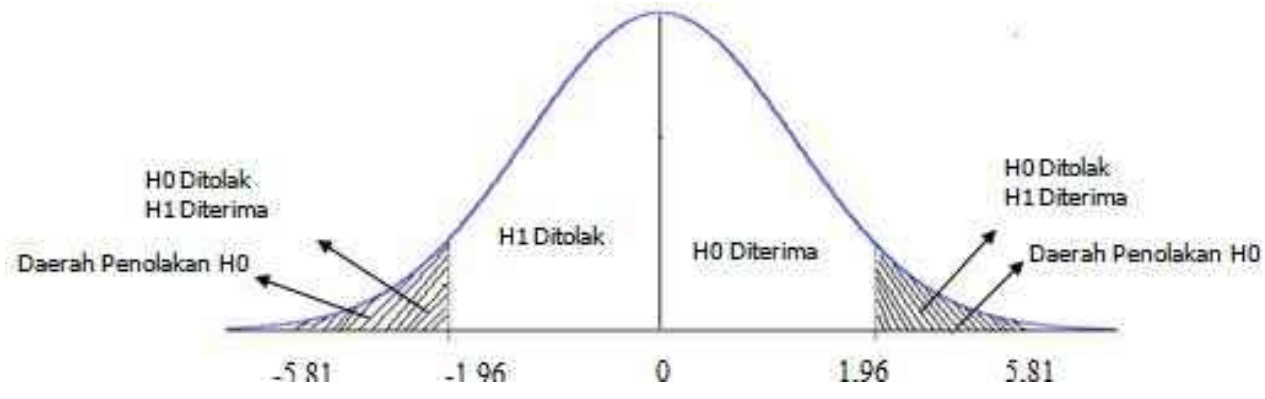

Picture 1.1

Acceptance Rejection region $\mathrm{H} 0$ and $\mathrm{H} 1$ 
To know the significance or relevance of correlation coefficients calculated above and to prove the hypothesis that has been made.

\section{Conditions:}

$(\alpha)=0.05$

where the test statistic used is:

$t=\frac{\mathrm{r} \sqrt{\mathrm{n}-2}}{\sqrt{1-r^{2}}}$

degrees of freedom $=n-2$

\section{Population and Sampling Techniques}

Population used in this study was The Junior High School Students in Bandung. The reason the researchers chose this population was due to the target of research where most users of Blackberry in Indonesia are teens. Grade 9 students are not used because the population according to the source of this research, they have focused on the activities of National exams. As a new grade 7 students did not do the registration and activities in the learning activities.

Sampling Techniques

Observed sample is part of a collection of objects. Given this sample, it is expected to demonstrate and describe the characteristics of the population ". (Grace, 1998:78). Due to the population to be studied too much, researchers drew most of the population to represent the entire population elements available. To the researchers conducted sampling technique, sampling techniques of the population.

To get the sample, the researcher used cluster sampling technique, by doing a lot of sampling stage (multistage cluster random sampling) (Aslichati et al, 2010: 5:27). There are 5 school regions in West Bandung district, East, Central, North, and South district. From each of region, it will be taken the School randomly as the samples. From 5 Juniro High schools, it was obtained 148 student as the respondents.

\section{Variables Operationalization}

Variable X: Intensity of Use Blackberry among Junior High School Students (Indicators: Intensity of Blackberry use, Duration of Blackberry use)

Variables Y1: Students' demand fulfillment (Indicators: Cognitive ,Affective Needs, tension release, integrative Personal, and Social Integrative.

Variable Y2: Personality Junior High School Students (Indicators: - Confidence, and Tolerance)

\section{Conclusion}

1. There is a very low relationship between intensity of use BlackBerry with cognitive needs of students SMP .

2. There is a low but definite relationship between the intensity of use of the BlackBerry with the affective needs of students SMP .

3. There is a very low relationship between the intensity of use of the BlackBerry with the release of tension SMP students . 
4. There is a very low relationship between intensity using a BlackBerry with a personal integrative needs of Junior High School Students

5. There is a very low relationship between intensity of use BlackBerry with social integrative needs of Junior High School Students .

6. There is a very low relationship between intensity of use BlackBerry with confidence Junior High School Students .

7. There was no relationship between the intensity of use BlackBerry with SMP Student tolerance .

8. There is a low but definite relationship between the intensity of use by meeting the needs of BlackBerry Junior High School Students as a whole

9. There was no relationship between the intensity of use BlackBerry with SMP students overall personality .

From the statistical analyses above, it can be seen that the intensity of Blackberry use had very little relationship or had no relationship with the students' cognitive, affective, tension release , personal integrative or social integrative. The intensity of Blackberry had also very little correlation with the students' confidence and tolerance. Therefore, parents or teachers should not be worried so much with the intensity use of Blackberry, since the result of the research did not find any worrying impact of the intensity use of Blackberry to students' demand fulfillment and personality.

\section{Suggestion}

1. Phenomenon blackberry use among adolescents is an exciting reality of communication research. It is advisable to do some research about the content (content) that can affect users, especially with regard to the information that can be uploaded, so it can affect communication patterns for the wearer.

2. Studies on the use of Blackberry by teenagers can be enriched by using qualitative research methods, such as methods of symbolic interaction.

3. The school suggested more assertive in disciplining the students to turn off or set to silent ring-clicking a cell phone carries. For the expected cooperation with the parents, to be proactive action in disciplining the use of mobile phones in schools.

4. The students are required to be guided to use Blackberry in a proper way, so the researcher gave them the guidance in the form of Pocket Brochure about SMART and WISE in USING BLACKBERRY.

\section{REFERENCES}

1. Albarricin, D., Wang, W., Li, Hong \& Noguchi, K., 2006. Structure of Attitude;Judgment, Memory and Implications of Change dalam Attitudes \& Attitude Change, New York, Psychology Press: Taylor \& Francis.

2. Albarricin, D., Johnson B. T. \& Zanna, M.T., 2005. The Handbook of Attitudes, New Jersey, Lawrence Elbraum Associate Publishers, Mahwah.

3. Azwar,Saifuddin.1995. Sikap Manusia, Jogjakarta, Pustaka Pelajar

4. Baldwin,John R, Stephen D Perry, Marry Anne Moffit. 2004. Communication Theories for Everyday Life, United States of America, Pearson Education,Inc.

5. Crano, W. D. \& Prislin, R,.2006. Attitudes \& Attitude Change, New york, Psychology Press: Taylor \& Francis.

6. Djali. 2007. Psikologi Pendidikan. Jakarta, Bumi Aksara.

7. Dalyono. M. 1997. Psikologi Pendidikan. Jakarta, Rineka Cipta.

8. Fisbhein, M \& Azjen, I. 1975, Belief, Attitude, Intention and Behavior: An Introduction to Theory and Research. Massachusetts,Addison-Wiley Publishing Company. 
9. Hanurawan, Fattah. 2010. Psikologi Sosial; Suatu Pengantar. Bandung, PT Remaja Rosdakarya.

10. Muhibin, Syah. 2002. Psikologi Pendidikan Dengan Pendekatan Baru. Bandung, PT Remaja Rosdakarya.

11. Oppenheim, A. N., 1992. Questionnaire Design, Interviewing and Attitude Measurement; New Edition, London, Continuum.

12. Gunarsa, 1988. Psikologi Remaja, Jakarta, BPK Gunung Mulia

13. Papalia Diane. E, Sally Wendkos Olds, Ruth Duskin Feldman. 2001. Human Development eighth edition. New York : Mc Graw Hill

14. R L Daft, R H Lengel, L K Trevino. 1987. Message Equivocality, Media Selection, and Manager Performance: Implications for Information Systems. USA, University of Minnesota.

15. Rakhmat, Jalaluddin. 2005. Metode Penelitian Komunikasi. Bandung, PT Remaja Rosda Karya

16. Santrock,John W.2001. Educational Psychology, New York, McGraw-Hill

17. Syamsuddin Makmun, Abin. 2003. Psikologi Pendidikan. Bandung : PT Rosda. Karya Remaja.

18. Sims, R. L. \& Gegez, A. E.. 2004. Attitudes towards Business Ethics: A Five Nation Comparative Study; Journal of Business Ethics. London.

19. Sumanto, Wasty. 2006. Psikologi Pendidikan Landasan Kerja Pemimpin Pendidikan. Jakarta, Rineka Cipta.

20. Walther,J.B. 1996. Computer Mediated Communication, Impersonal, Intrapersonal, and hyperpersonal Interaction, Communication Research, 23, 3-43.

21. West, Richard \& Lynn H. Turner. 2008. Pengantar Teori Komunikasi Analisis dan Aplikasi. (Terj. Maria Natalia Damayanti Maer). Jakarta, Penerbit Salemba Humanika.

\section{Other Source}

Miller,1995.The Presentation of Self in $\quad$ Electronic $\quad$ Life:Goffman $\quad$ on $\quad$ The
Internet.http://ess.ntu.ac.uk/miller/cyberpsych/goffman.htm

